\title{
Moving to dangerous places
}

\author{
Eberbard H. Weber, Priya Kissoon, and Camari Koto
}

\begin{abstract}
Mobility is an important part of the discourses around climate change. Many argue that mobility in connection to climate change, natural hazards, or similar is about bringing people to safety, supporting them in their own efforts to reach safe grounds, or as McAdam (2015) puts it: taking people away from "danger zones".

This chapter investigates mobility of people living in informal settlements in Suva, the capital of Fiji, which are exposed to hazards . This chapter, hence concentrates on people moving to highly exposed areas. How can we explain when people move to 'danger zones' like is happening in many informal settlements in the Pacific Islands (and surely elsewhere)? Are people not aware that the locations are dangerous, do they not bother to find out, or do they consciously choose such 'danger zones'?

For our study, we undertook interviews and observations in two informal settlements in Suva. Our research suggests that the two locations where people established informal settlements were chosen at least in part because of their unfavourable environmental conditions. Whether this occurred consciously or more in a reflexive learning process that directed people to locations where they did not face evictions needs to be established in future research. It is becoming evident, however, that in Suva space is becoming scarce. Locations that nobody was interested in several decades ago are now in high demand. This also puts people who live in informal settlements at risk of being evicted by governments' plans of relocation and/or by market forces, which can be seen as a special form of gentrification.
\end{abstract}

Cite this article: Weber, E., Kissoon, P., \& Koto, C. (2019): Moving to dangerous places. In: Klöck, C. \& Fink, M. (eds.): Dealing with climate change on small islands: Towards effective and sustainable adaptation? (pp. 267-291). Göttingen: Göttingen University Press. https://doi.org/10.17875/gup2019-1220 


\section{$1 \quad$ Introduction}

For a long time, research on the impacts of and adaptation to climate change in the Pacific Islands region excluded urban areas almost entirely. This is surprising since in many Small Island Developing States (SIDS) in the Pacific a considerable share of the population lives in urban areas (Mycoo \& Donovan, 2017). Urban growth rates are among the highest in the world, particularly in the SIDS of Melanesia (Butcher-Gollach, 2015, 2018; Kiddle, McEvoy, Mitchell, Jones, \& Mecartney, 2017; Mecartney \& Connell, 2017).

Urban spaces in the Pacific Islands have grown significantly over the past few decades. Many migrants arriving from rural peripheries in urban centres have taken up residence in informal settlements that are often characterised by very poor environmental conditions (Kiddle, 2010a, 2010b, 2011; Kiddle \& Hay, 2017; Jones, 2016a).

While much research has been done on the drivers of rural-urban migration (see for more recent examples Duda, Fasse, \& Grote, 2018; Friend et al., 2015; Yalew, Hirte, Lotze-Campen, \& Tscharaktschiew, 2018), relatively little is known about the considerations people undertake in choosing where exactly to settle in urban areas (Augustijn-Beckers, Flacke, \& Retsios, 2011; Babere, 2015; Fleischer, 2007; Loibl, \& Tötzer, 2003). It is assumed that the distance to places of employment plays a role (Reza, 2017), but systematic research on this and other aspects is minimal (Huang, Parker, Filatova, \& Sun, 2014).

With climate change adaptation becoming a major concern, the question of human mobility and its relevance to climate change adaptation is becoming increasingly important. Already today many islands in the Pacific are exposed to the impacts of climate change. In a number of cases where states consist only of atolls and/or lowlying coral islands, entire states might disappear since there are no places within these countries' territories where people can safely resettle (Weber, 2015, 2016; see also Duvat \& Magnan, this volume).

With these arguments in mind, it appears contradictory and is difficult to explain when people move to 'danger zones' like is happening in informal settlements in the Pacific Island region (and certainly elsewhere). Are people not aware that these locations are dangerous, do they not bother to find out, or do they consciously choose such 'danger zones'?

This chapter reflects on the causes of mobility from a livelihood and risk mitigation perspective. It looks at two informal settlements in a part of Suva, which a couple of decades ago were at the very periphery of Suva city. Over the past 30 years, however, this area has become a place of sustained investment. When people moved to Suva some decades ago, they found protection from eviction in these environmentally disadvantaged locations. Today this part of Suva has become a prime location for high-cost residential and commercial development. People in informal settlements more and more frequently face challenges to be able to stay in this part of Suva. Some settlements have been identified for relocation, and aspects of gentrification are visible in others. 


\section{$2 \quad$ Migration and mobility}

\subsection{Climate change and human mobility}

Social scientists who study the causes and motivations of migration have produced various explanations over time. Ravenstein's seminal contributions $(1885,1889)$ later led to concepts of push/pull factors, which have a very long tradition in migration studies (Van Hear, Bakewell, \& Long, 2018). Scientists investigate the economic, ecological, or social properties of space (Adger \& Fortnam, 2018; Dorigo \& Tobler, 1983; Lee, 1966; Marino, 2018). They conclude that migration happens from locations endowed with (relatively) lesser qualities to locations where the qualities are higher.

In climate change discourses, a particular push factor is added: people leave places where they have been living because climate change makes these places 'dangerous'. Publications on people's mobility as a response to and result of climate change often argue that the impacts of a changing climate can be considered as a force that drives people away from their homes, looking for safety and security elsewhere (McAdams, 2015). The argument is that migration happens because climate change puts people's lives and livelihoods at risk. From such a perspective mobility becomes an action to adapt to or cope with adverse situations, to secure livelihoods or strengthen resilience (Weber, 2014).

Push/pull dynamics, however, are obviously not sufficient to explain migration comprehensively: if only spatial properties/qualities are used to explain migration then it becomes difficult to explain why some migrate and others don't when they live in the same location. Investigations that consider actors and their agency are urgently needed to close this gap (Bohle \& Fünfgeld, 2007; Long, 2001; Otsuki, Jasaw, \& Lolig, 2018). Agency refers to individuals' capacity "to act independently and to make their own free choices" (Fazey et al., 2015, p. 200): not all people have the same goals and aspirations and the same opportunities to accomplish them. Aspirations, wishes, and fears lead to different perceptions of space and differing opportunities and constraints allow or disallow people to achieve what they aspire to (Carling \& Collins, 2018).

\subsection{The search for wellbeing and security}

In addition to hunger, war, violations of human rights, and poverty, the degradation, pollution, and destruction of the physical environment have been named by social scientists as reasons for forced migration (Weber, 2014). It is often assumed that environmental change (including climate change) has become a reason for people to involuntarily leave the places they live in (Biermann, 2001; Lonergan, 1998). Declining environmental quality, including impacts of natural hazards, is putting people's lives and livelihoods at risk. Many social scientists agree that migration and the quality of the environment are related in many cases. Details of how such a relationship can be conceptualised, however, remain heavily disputed. 
It often remains unclear if in these cases environmental change is the only driver of migration or if the decision to move is the result of (more) complex processes and deliberations (UK Government Office for Science, Foresight Report, 2011).

Migration serves many purposes. The migration of poor, insecure, and underemployed people from rural areas often follows the rationale of aiming to enhance wellbeing and - even more important - to minimise risk and gain security (Adger \& Fortnam, 2018; Tian \& Lemos, 2018). Rural areas often do not provide full employment for everyone of working age (Singh, Singh, \& Singh, 2015; Yeboah \& Jayne, 2018). People's capacities and capabilities are under-utilised (Mukhtar et al., 2018). Employment in these areas is also often limited to one or a few sectors. The advantage of having employment in various sectors, from subsistence production to international capitalist production, which more often occurs in cities, enhances security since dependency on one particular mode of production constitutes a huge risk.

In many cases, migration supports people in their efforts to diversify their livelihoods and to reduce the risks that they face (Friedman, Hirons, \& Boyd, 2018; Woodhouse \& McCabe, 2018; for research that is critical of this perspective: Cochrane \& Cafer, 2018; Ebenezer \& Abbyssinia, 2018). The importance of livelihood diversification to reducing vulnerability figures very prominently in the concept of resilience to the impacts of climate change and natural hazards (Ajak, 2018; Jurjonas \& Seekamp, 2018), as well as in the "Sustainable Livelihood Approaches", which are, however, often lacking theoretical depth (De Haan \& Zoomers, 2005). In one way or another all of the approaches mentioned above take up the notion of 'translocality' and relate it to people's search for wellbeing and security (Carmo \& Hedberg, 2018; Etzold \& Sakdapolrak, 2016; Islam \& Herbeck, 2013; Keck \& Sakdapolrak, 2013; Rockenbauch \& Sakdapolrak, 2017; Sakdapolrak et al., 2016; Steinbrink, 2009; Weber, 2017). To reach common ground across many disciplines and details, translocality can be seen as referring to the structures and processes in which mobile people "are locally grounded and where transnational ties are regulated and institutionalized" (Stephan-Emmrich \& Schröder, 2018, p. 28).

De Haan (2000) similarly argues that geographical differentiation (e.g. rural versus urban, national versus international) does not show the proper space in which translocal social units are operating. What the Migration Remittances, Aid, Bureaucracy (MIRAB) model calls the "transnational corporation of kin" (Bertram \& Watters, $1985,1986)$ indicates that social units operate across space. They forge rural-urban relationships, where exchange of goods, money, and people is perpetuated for the purpose of optimising economic and social wellbeing. Linking rural and urban spaces creates hybrid households which operate in different places (translocal) and also have considerable circulation of their members (being one day here and the other day there). Households constitute coherent social units that operate across distances (Lohnert \& Steinbrink, 2005; see also Schiller, Basch, \& Szanton Blanc, 1995). All these are crucial elements of translocality.

Additionally, much information is available on why people move to informal settlements within the Pacific region, and Fiji in particular (Bryant, 1992, 1993; 
Bryant-Tokalau 1995, 2010; Jones, 2012a, 2012b; Mohanty, 2006a, 2006b). The debate on 'affordable housing' in urban areas has been a long-lasting one, but so far no solutions are visible regarding how to provide affordable urban housing to poorer strata of Suva's population (Bryant-Tokalau, 2014). Already in 1992 BryantTokalau focused her study of poverty in Fiji on urban informal settlements, where the conflict between high costs for formal accommodation and low incomes is very meaningful (Bryant, 1992; see also Bryant-Tokalau, 1995 for Fiji and Vanuatu). Jones (2012b, p. 327) remarks that "both rural and urban poverty cannot be divorced from squatter and informal settlements and vice versa, as it is now well accepted that the majority of the Pacific urban poor gravitate to and live in squatter and informal settlements."

To summarise: People use migration as a strategy to secure and strengthen their livelihoods, to minimise risk through livelihood diversification. This is a response to insecurity because of under-employment, seasonal employment, low wages, high dependence on primary production, and high vulnerability to disturbances of ecosystems, among other reasons (see, among many, Carney, 1998; Ellis, 2000; Scoones, 1998).

The parallels to push/pull considerations are striking, but only at the places of destination (such as in the informal settlements in Suva). During our fieldwork, of course, only those who had migrated were considered. Others, who stayed back in the villages do not figure here. Another element becomes essential: people's reflexivity, their autonomy to make history (Archer, 2007), the ways in which they follow their aspirations. Reflexivity, however, also means that actors learn by doing. It is not that people evaluate their situation in advance and reach logical conclusions that govern their actions. Instead they respond to situations, seize opportunities that open up, and learn along the way how to improve outcomes (Archer, 2007, 2010; Davidson, 2012; Prowse, 2010; Schilling 2012). People "cannot know everything that is going on" (Archer, 2007, p. 17), and as a result they have to improvise and learn step-by-step through their experience and their reflection on it. This is particularly important with regard to migration because moving elsewhere is filled with 'unknowns' and people are unfit to consider and evaluate all possibilities for action and make rational decisions (see also Otsuki, Jasaw, \& Lolig, 2018).

\section{Urban space in the Pacific Islands}

Urban settlements in the Pacific Islands are tiny compared to global standards (Cocklin \& Keen, 2000; Jones, 2016). They are young by any standard. The oldest hardly reach 200 years in age. All are the result of European arrival and intervention in the Pacific Islands region, which started in the $18^{\text {th }}$ century when whaling vessels were looking for places to restock provisions and water. At the whaling stations a few Europeans settled, but these conglomerations of a few Europeans' houses lacked what today we would consider urban functionality. Around the same time beachcomber communities were established where individual Europeans 
integrated into local communities, and "went native" (Bargatzky, 1980; Campbell, 1998; Milcairns, 2006; Ralston, 1977).

Urbanisation in a more comprehensive way stepped up when more and more Europeans, many of them coming through Australia and New Zealand, settled in the Pacific Islands to establish trade relationships (Weber, 2017). Individuals, first living with indigenous inhabitants and later operating from port towns, started trading with the extraction of sandalwood, bêche-de-mer, turtle shells, pearls, and other exotic commodities (Ralston, 1971). Later companies such as Burns, Philp \& Co Limited, Goddefroy and Sons, and Hennings concentrated on agricultural commodities: first coconuts to produce copra and coconut oil, then cotton, and finally sugar cane.

Urban areas in the Pacific Islands were miniscule until the 1960s, which marked the beginning of independence for most Pacific Island countries. In 1911 the urban population of Fiji had been around $4 \%$ of the overall population (Chandra, 1985). In 1966 a third of Fiji's population lived in urban areas (Chandra, 1985) and by 2004 the 50\% mark had been crossed (ADB, 2012). In the census of 2017 around $57 \%$ of Fiji's population was listed as urban (Fiji Bureau of Statistics, 2018).

When the first Pacific states achieved independence, modernisation optimism prevailed, which considered urban areas as the centres of economic and social innovation and development. Not much later it became evident that a fast-growing urban population entails unresolvable social, ecological, cultural, and planning challenges. In particular, urban development lagged behind in the provision of infrastructure, including low-cost housing for a rapidly increasing urban population. In the capitals of many Pacific Island countries, informal settlements mushroomed; biggest in terms of population and size are the informal settlements of Greater Suva, but informal settlements burgeoned also in Honiara, Solomon Islands (Foukona, 2015; Keen, Barbara, Carpenter, Evans, \& Foukona, 2017; Moore, 2015), Port Moresby, Papua New Guinea (Jones, 2012), and Port Vila, Vanuatu (Trundle, 2017). Many of these informal settlements were established at locations that have adverse environmental conditions. Often these conditions are severe and detrimental to human habitation; by any means these places are 'dangerous places'.

\section{$4 \quad$ Reflection on the case study in Suva}

The case study on which this chapter is based investigates people living in informal settlements in Suva, the capital of Fiji. The investigation concentrates on people's actions in space, especially their mobility. The case study takes up climate change as a possible driver of migration only indirectly: when it is argued that spatial characteristics are less relevant to people's mobility than their agency, their opportunities and constraints to be mobile, then all causes of mobility that relate to spatial characteristics become of secondary importance. What counts is not that people want to migrate because conditions in the places they live have become too pressing. Far more important is whether people are able to move, or whether con- 
straints are so huge that they have to remain where they are, even if their desire to leave is overwhelming.

Research to obtain information was conducted in mid-2016 in the informal settlements of Muanivatu and Veidogo in the eastern outskirts of Suva. In each of the two settlements semi-structured interviews with a mix of open and closed questions were conducted. Mainly questions that relate to people's agency supporting or preventing mobility, processes of reflexivity, and underlying socio-political aspects of urban change in the eastern rim of Suva city are addressed in this chapter. Interviews were conducted with one adult person in 50 households, which were randomly chosen for the study. The purpose of the overall fieldwork was to look into people's livelihoods, their mobility backgrounds and histories, their connections to households elsewhere, as well as issues of environmental health arising from adverse properties of the settlements under investigation.

Perspectives are presented in this chapter that relate to people's selection of places to settle. By applying such a spatial dimension to people's aspirations, the overarching aim is to investigate the dynamic properties of space and its consequences for vulnerable people's actions in space. The objectives to gain more knowledge concentrate on three issues. The first relates to the question, "What role did security/insecurity play when people selected a particular informal settlement?" This question had to be slightly modified because in interviews it turned out that quite a number of people did not find a suitable place right from the beginning. Many had to shift residence after their arrival in Suva. At this point the notion of reflexivity was introduced as a process that guided people in improving selection criteria. The second issue relates to the question, "Why were people willing to settle in locations that expose them to severe health risks?", and the third relates to the question, "How did people's action in space become constrained through economic dynamics when places once in Suva's periphery became attractive investment objects?"

This chapter reports on an activity in progress: two months of empirical work were completed in 2016. Some results from then were analysed for the presentation at the conference in Hannover and the preparation of this chapter. In addition, all qualitative information provided by people during fieldwork in 2016 has been assessed to provide deeper insights than a quantitative analysis could have achieved. A second round of investigation is planned, concentrating exclusively on people's criteria used when selecting a place to settle.

The settlements of Muanivatu and Veidogo are in the eastern part of the Suva peninsula along Fletcher Road, which starts at the Marine Campus of the University of the South Pacific (USP) and ends at Nabua, a part of Suva town (see Figure 1). 


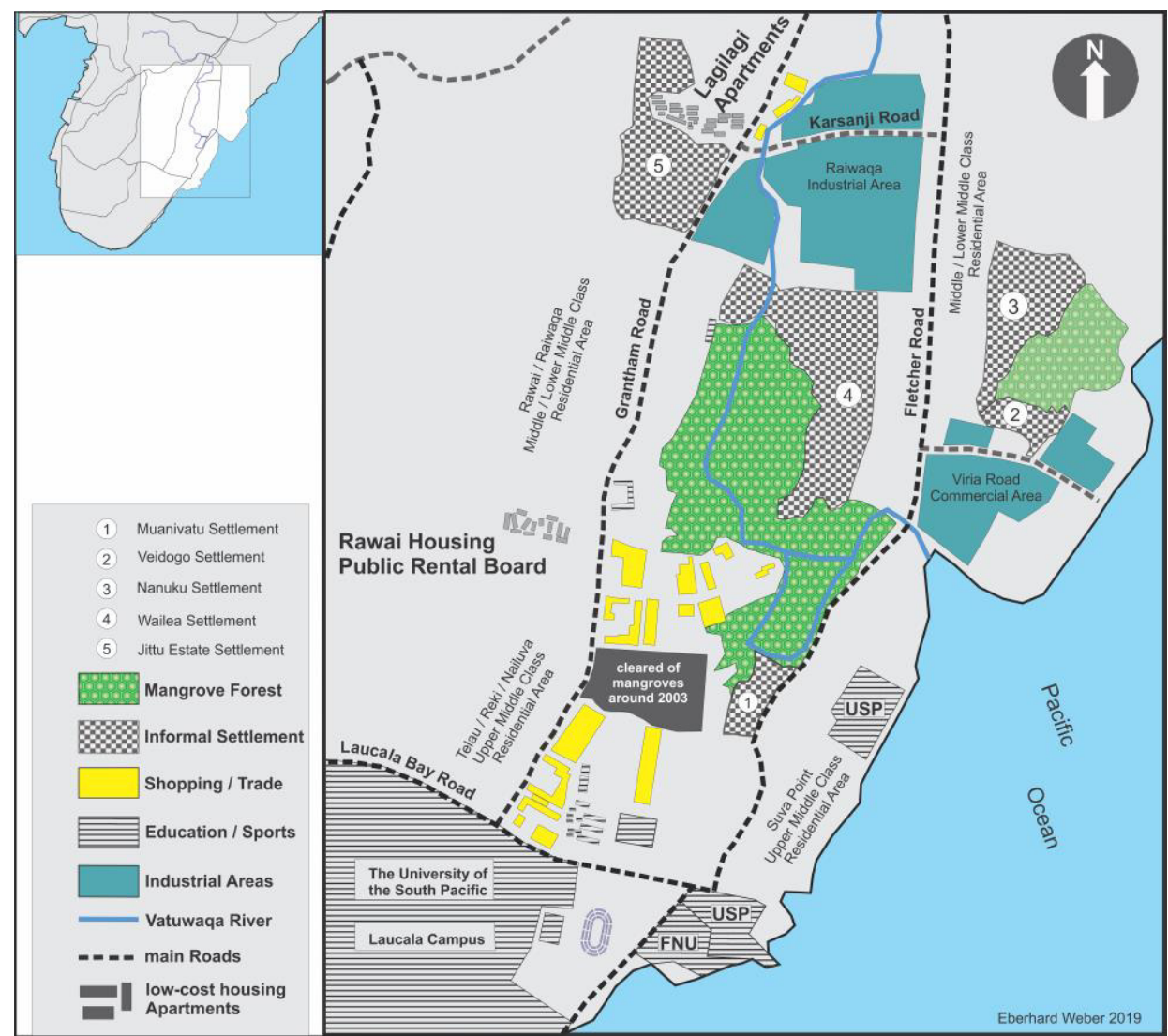

Figure 1: The Eastern Rim of Suva City. Source: E. Weber.

Today both settlements are located on prime real estate properties in an area of Suva City, which has been quickly expanding in the past three decades (see also Bryant-Tokalau, 2014). When the first informal settlements in this part of Suva were established they were at the periphery of the city in an area without much development interest.

Muanivatu and Veidogo are not the only informal settlements in this part of Suva: close to middle-class formal residential areas, often in third line to the main road, Suva's largest informal settlements are located here (Jittu Estate, 639 households with 2,910 residents, and Wailea, 402 households with 1,922 residents). Muanivatu with 70 households and 324 residents and Veidogo with 130 households and 650 residents, as well as Nanuku with 215 households and 927 residents, are smaller settlements (all figures according to Government of Fiji, 2006).

Muanivatu and Veidogo are mixed in their ethnic composition. Native Fijians (iTaukei) form a majority in both settlements. In Muanivatu around 60\% of the peo- 
ple are of iTaukei ethnicity and in Veidogo $70 \%$. The rest in both settlements are predominately Fijians with Indian ancestry and less than $5 \%$ are other ethnicities.

Both settlements have been built into the mangrove forests of the area. Indeed, the Fijian word 'Veidogo' means 'Mangrove Swamp'. Especially in Muanivatu's case, much of the mangroves that were once west and south of the settlement have been cleared for development activities in the past three decades (see also about the clearing of the tiri (mangroves) (Bryant-Tokalau, 2014).

In the past 60 years the Vatuwaqa River has lost much of its catchment area. Earlier, excess water during heavy rainfall could spread, mitigating floods. Today the drainage situation in Muanivatu has deteriorated. Flooding occurs more often and is more severe. The latest destructions of a huge area of mangrove forest west of Muanivatu happened around 2013 when mangroves were cleared for the construction of a huge shopping complex. Six years later construction has not even started.

Muanivatu was established rather recently. The settlement increased from 7 houses shown on aerial images in 2002 to almost 100 houses in 2019. In its rather short existence, people in the settlement have been served with five eviction notices from the Suva City Council. In one case they were given only 24 hours to leave. Support from local NGOs allowed the community to stay (Asian Coalition for Housing Rights in Suva, Fiji [n.d.]). In 2018 Muanivatu was included among 11 other informal settlements that are earmarked to be upgraded by RISE (Revitalising Informal Settlements and their Environments), a project led by MonashUniversity, Melbourne (RISE 2018).

Veidogo has existed much longer than Muanivatu. During interviews, some people mentioned that their families have lived in the settlement for more than 70 years. If this is correct it would mean that some houses in the settlement existed already in the 1940 s and 1950 s.

\section{$5 \quad$ Results}

\subsection{In search of security: moving to the city}

Most residents of Muanivatu and Veidogo who participated in the research are not native to Suva. Many households had complex migration histories before they settled in the places where they live now. In quite a number of cases the first family members arrived in Suva a couple of decades ago. About half of the members of the iTaukei community had migrated from rural areas directly to one of the two settlements; the remaining had earlier lived in other parts of Suva.

iTaukei households are often fragmented in the sense that parts of the families continued to live in the location of their origin in rural areas. Movements between rural and urban areas have been rather dynamic and the composition of households as a result has been changing considerably over time. 
Households of Fijians with Indian ancestry differ in a number of characteristics from iTaukei households: What is similar are the complex migration histories of many. With a few exceptions, however, Fijians of Indian origin arrived with their entire family leaving nobody behind in the rural areas they had come from. They often arrived from sugar cane growing areas of Vanua Levu around Labasa and Sequaqa. They had to abandon their homes when the leases were not renewed starting in 1997. Expiring sugar cane leases forced a large number of Fijian farmers of Indian ancestry to migrate to urban areas, the majority of them to Suva. By 2018 some 12,000 sugar cane leases were expected to expire (Naidu \& Reddy, 2002). Many of them were not renewed, especially in the years up to 2006 (Weber, 2005, 2007a, 2007b). This deprived farmers not only of access to land to earn a livelihood, but also of housing, since in most cases the farm houses had been built on leased land. The expiration of sugar cane leases uprooted people from the areas they had lived for generations. Unlike iTaukei they usually could not continue a family presence in the places they came from, but had little choice other than to move with the entire family to urban areas where most of them ended up in informal settlements. Here agency, meaning the capacity of individuals to act independently and to make their own free choices, found a limitation: structural violence (Galtung, 1975; Weber, 2012) forced families to leave where they had lived for decades.

When asked for the reasons why their household had come to Suva, people's answers concentrated on aspects of employment (almost half of the participants in both settlements). Family reunion, family conflicts, and marriage were also mentioned rather frequently. None of the participants in the interviews mentioned climate change or related difficulties in their home villages as a reason for coming to Suva. For the participants of Indian ancestry, a few noted that the reason they came to Suva was the expiration of their land leases. Most Fijians of Indian ancestry who participated in the study, however, had come to Suva already before the land lease problems started in 1997. It appears that Fijians with Indian ancestry rarely visit relatives in the places they lived before coming to Suva. The prevalence of this is much higher in iTaukei communities where people from around $60 \%$ of the households visit their native village at least once a year. In most cases, such visits happen more frequently and often there is frequent movement to and from native places, which coincides with the movement of goods and money.

As mentioned above, none of the people interviewed mentioned climate change as a consideration for why they had come to Suva and/or settled in a particular location. Still, many mentioned that climate change is important in their lives. Issues that people brought forward include: (i) Many settlements are built into mangrove forests. As a result, they are flooded twice a day during high tide. Many conversations with people indicated that they are aware that this exposure to floods intensifies with climate change. (ii) Housing construction in informal settlements is usually sub-standard. Most of the houses in Suva's informal settlements won't be able to withstand the forces of strong tropical cyclones. In February 2016, Tropical Cyclone Winston devastated many parts of Fiji, killing 45 people its path (EM-Dat Database, Brussels). Just a few hours 
before Tropical Cyclone Winston made landfall, its path was directed straight towards Suva. If Suva is directly hit by a category 5 cyclone, the damages and death toll will surely be much higher than in 2016.

Rural to urban migration continues to play a considerable role in Fiji. Today climate change might play a bigger role in people's decisions to leave their villages although there is very little evidence that rural communities are more exposed to impacts of climate change than urban ones. It is also unreasonable to assume that people leave the security of the villages and indeed move to 'safer' places when migrating to informal settlements in urban areas. Most cannot afford to live anywhere else than in these settlements where they are exposed to considerable health risks and other dangers. As long as migration can help them to diversify their livelihoods and contribute to the resources of people living in their native places, they shall continue to come to Suva.

Our understanding of this last aspect has been deepened through the interviews: participants were asked how they perceive their family in their native places, and how they consider exchange of goods and money. Among the iTaukei an overwhelming share in both settlements perceived the family "back home" as part of their household with which they frequently exchange goods and money. Mobility is much more dynamic than the word 'migration' is usually understood. People are members of the same household, who live and work in at least two, but often more, places. Movements occur between these sections of the same households in a rather unpredictable and asymmetric way: some household members have migrated in the way it is usually understood. They have established permanent residence, have taken up jobs, which at least they hope are permanent (which is often not the case), and intend to stay in Suva at least until retirement.

\subsection{To move to Muanivatu or Veidogo}

People from rural areas who come to Suva are usually unable to pay high rents or purchase properties in the formal housing market. Many participants in interviews explained that they depend on informal arrangements to have access to cheap accommodation. To have no such access is a huge constraint, which often prevents mobility from happening since many people do not have the resources to live anywhere else than in an informal settlement.

Still it is interesting that almost $20 \%$ of the people interviewed in Veidogo and close to $10 \%$ in the case of Muanivatu stated that they had purchased the house to which they moved in the respective settlement. Publications on informal settlements in Suva often neglect this aspect of internal consolidation which can lead to considerable dynamics in a settlement without adding much to its size.

In contrast to research on why people move to informal settlements (see section 2), knowledge about the selection of a particular settlement is extremely scarce. There are 85 informal settlements in Greater Suva. Migrants thus can choose from a large number of locations where they can establish residence. 
Social capital, the benefits of being part of networks that provide support in issues of migration, finding employment, and so on, plays an important role when people make choice about where exactly to move. The majority of participants in the survey (about 70\% in the case of Muanivatu and almost 60\% for Veidogo) knew people in the settlement before they moved in. This is especially interesting in the case of Muanivatu, which is a rather young settlement. In the past 15 years, the settlement increased considerably in size and population. Quite a number of people moved there as kin groups establishing several houses at the same time. As Veidogo is much, much older it has been impossible to get a clearer answer whether people arrived as individual households or several related households at one time.

\subsection{Trading health security for security from eviction}

When discussing the environmental situation in both settlements, a great majority of people (for both settlements more than $70 \%$ ) admitted that they do not bother too much about detrimental environmental conditions. Already in the preparation for the study some people highlighted that indeed the difficult environmental situation protects them from being evicted. During interviews, when this issue came up again and again, it was addressed more systematically: many participants reported that they or their parents or grandparents have experienced a couple of times being evicted from places where they had settled before. This was very obvious particularly for Veidogo: out of those who moved to Suva more than two decades ago slightly less than half reported that people in their family had the experience of being evicted. For Muanivatu, the share with such experience is less than half of this figure, but still significant.

It often took households some time before they found a place that appeared would make them safe from eviction. People indeed made decisions based on the experience that particularly unfavorable environmental conditions provided the best security from eviction. According to participants in interviews, for example, there is a relatively large number of residents of Veidogo (and Nanuku, which is not part of this study) who had been evicted from land in Raiwaqa when Raiwaqa Industrial Area was established in the 1980s.

Veidogo, as well as Nanuku, being built into the mangrove forest, became the ideal locations to establish residence. Nobody other than the settlers were interested in living in these locations or in using the mangrove land for other purposes. In other places, people were asked to remove their houses soon after they had established them. When land was needed to establish Raiwaqa Industrial Area, many residents there had to move because the land belonged to a wealthy family, who had migrated to the United States but still owns much land in this part of Suva.

Around $80 \%$ of participants in the study in both settlements indicated that they are aware of the adverse environmental conditions they are exposed to. Nobody denied this, but a rather high percentage of participants $(20 \%)$ had chosen 'do not know' as a response when asked about this. Issues around water (in the range of $50 \%$ of reported 
environmental concerns) are by far the most prevalently reported. Although people differed slightly in expression (flooding, high tide, waterlogging) they all meant essentially the same thing: twice a day, the settlements are flooded as a result of tidal activities. Houses are rarely flooded, but the ground becomes very muddy even during low tides and causes severe inconvenience for people walking between the houses. The situation worsens especially in Muanivatu when heavy rainfall makes the Vatawaqa River rise. As most mangrove forests west of the settlement have been removed recently, flooding has significantly increased. During extreme flooding, septic tanks overflow and surface water mixes with sewage, causing severe health hazards.

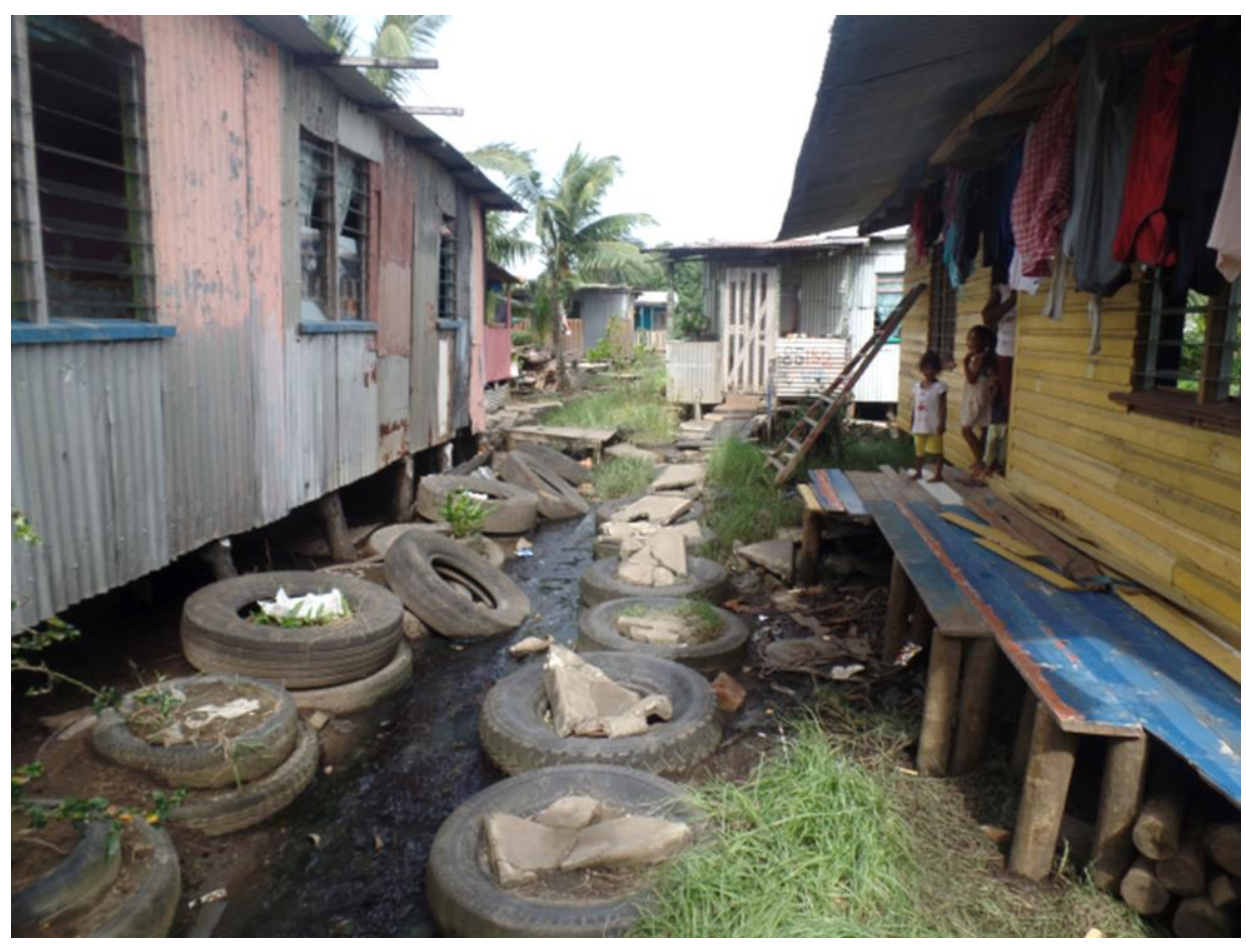

Figure 2: Coping with flooding in Veidogo settlement, June 16, 2017. Source: E. Weber

About $10-15 \%$ of the participants (more participants in Muanivatu than in Veidogo) see issues around sanitation as a serious environmental concern. Since flooding and the situation around sanitation are closely related it is likely that many participants alluded to the combination of water and sanitation when they gave their responses.

Many participants are also concerned about rubbish and the dirty appearance of the settlements. People express that little care is given to the disposal of rubbish. Between 10 and $15 \%$ of responses referring to environmental challenges in the two settlements mention this issue. 
People are aware that the situation they live in can have severe consequences for their and their children's health. Almost three quarters of participants in the study agree or strongly agree that flooding and/or waterlogging threaten their health. Expressions of concern were slightly higher in Veidogo (74\%) compared to Muanivatu $(69 \%)$.

Overall, it is evident that the adverse environmental situation in the informal settlements constitutes extreme health risks to the people of Muanivatu and Veidogo. People don't consider this as an unwelcome 'side-effect' of living in an informal settlement, but a precondition to enable them to live in an urban area, close to their places of employment without constant fears of being evicted. "We know that it is not good for our children to live here being exposed to all the mud and dirty water. However we cannot afford to live in a better place. At least nobody else wants to live here and therefore we are not asked to move away" (Jone, 35, Muanivatu). The importance of protection from mud, water, and human and animal feces is shown in the efforts people exert to create walkways that keep them away from the filthy and unhealthy ground, littered with such things as car tires, as illustrated in Figure 2. In Veidogo settlement, residents have created a wooden walkway that allows them and their children to walk comfortably above the ground. In addition, the RISE Project (see below) aims in the first place to improve sanitation in informal settlements to make the environment healthier.

\subsection{Human security and urban expansion}

The notion of enhancing security by settling in 'dangerous places' finds its limitation in the rapid expansion of Suva City. Land, which earlier nobody wanted to occupy except the informal settlers, is now in high demand. Because of land scarcity for expansion of industries, trade, and apartment blocks for high income earners, second and third grade land is being used. Although development costs are considerably higher in such areas than elsewhere, investment is occurring.

The area between Grantham Road in the west and Fletcher Road to the east is such a location (see Figure 1). In the past 40 years, development activities in the area have been very dynamic. Aerial images over the past 40 years give a good idea of these development dynamics. Along Grantham Road there had been little development by the end of the 1970s. At this time the area was still in the very periphery of Suva. Extended mangrove forests occupied about half of the area. The big Raiwaqa Industrial Area did not yet exist. Today, Karsanji Road is the northern connection between Grantham and Fletcher Road. In aerial images of the mid-1980s neither Raiwaqa Industrial Area nor Karsanji Road exist.

The higher middle-class residential area of Suva Point, in the very southeastern part of the area, east of Fletcher Road, did already exist. North of the Vatuwaqa Bridge, to the eastern side of Fletcher Road, there was already in the mid-1970s Viria Road Commercial Area, the biggest commercial area in this part of Suva. To the left and right of Fletcher Road, lower middle-class houses werre lined up all the 
way to Nabua. At that time, in a third row away from Fletcher Road, just north of the Viria Road Commercial Area, there were some 30-40 houses in the location that today comprises the Veidogo and Nanuku informal settlements. East of Fletcher Road there were some 40 small houses in the area which today is known as Wailea informal settlement.

\subsection{Challenges to human security in informal settlements}

In such dynamic environments, informal settlers face increasing difficulties to coexist with commercial and real estate interests. It comes as little surprise that over the past 20 years repeated attempts have been made to relocate informal settlements to areas further into the periphery of Greater Suva. The locations between Grantham and Fletcher Road are slated to receive a 'social uplift', a special version of gentrification, a process of uplifting sub-standard urban neighbourhoods and exacerbating social differentiation and exclusion that comes along with such development.

Attempts to give the whole location a social face-lift have started with the imminent resettlement of people living in informal settlements. Already in 2009 and then again in 2016 the Fiji government announced plans to resettle the residents of Nanuku and Veidogo. In 2016, the Attomey General met with residents of these two settlements to inform them of this decision (Pratibha, 2016; Rainima, 2016; Shanal, 2016; Vakasukawaqa, 2016). Land in Makoi, some $10 \mathrm{~km}$ away has been identified as the site to where they will be resettled. By mid-2019, the resettlement had not yet started, but in October 2018 announcements in the public media suggested that the resettlement will be carried out within the next 9 to 12 months (Begum, 2018).

The land in Makoi has been identified and sub-divided, and utilities such as water, electricity, and sewerage have been established. The people will receive a 99-year lease on the land on which they are supposed to build their new homes. Each family will also receive an amount of FJD 1,000. Discussions with families have also revealed that they expect that banks will provide mortgage loans of up to FJD 10,000 which they can use to build their houses. This is a very dangerous point and NGOs need to enhance people's financial literacy to assure that loans are repaid according to schedule. Otherwise it can easily happen that houses will come to belong to the banks after a while.

It appears that the people of Muanivatu settlement will be able to stay. Over the next few years, until 2023, the settlement is earmarked to be upgraded under the RISE project. RISE aims to revitalise informal settlements through water sensitive approaches that are cost-effective and improve environmental conditions. Muanivatu is an ideal location for such efforts. The mangroves of Vatuwaqa River have been degraded over decades. To restore this ecosystem it is essential to keep one of the last extended mangrove forests within the boundary of Suva City. It is unclear whether this can succeed as the mangroves and several informal settlements are on prime real estate. It is also uncertain whether after the successful completion of the RISE project the people of Muanivatu will be able to remain 
there, or whether after a while they will be replaced by people who are financially better off.

Around 2008, the apartment blocks of the Public Rental Board (PRB) at Raiwai and Raiwaqa were demolished. On September 1, 2014, Fiji's Prime Minister Bainimarama opened new apartment housing of the PRB not far from where the old PRB apartments at Raiwai had been. This was less than three weeks before Fiji's first general elections since 2006. ${ }^{1}$ Towards the northern end of Grantham Road another apartment complex for low-income groups was established around the same time. The Lagilagi Housing Project was inaugurated in April 2015 to provide affordable housing to low-income groups. The Lagilagi Housing Project is carried out by a local NGO, the People's Community Network (PCN), with support from the government of Fiji and international funding from a German Catholic development agency. Apartments provided by the PCN are for poorer families, especially those who have lived in nearby informal settlements. Waiting lists are long, and once given an apartment people need to pay one third of the cost over a period of 12-15 years. Occupants receive a title which keeps the property under the care of the PCN. An apartment cannot be sold to illegitimate persons. If people wish to move away, they sell back their unit to the PCN (personal interview with PCN Director; see also Bryant-Tokalau, 2014). In November 2018, newspapers and TV stations in Fiji reported that a large number of occupants of Lagilagi apartments have never lived in informal settlements. It is alleged that they stay illegally in the flats. There are also reports about delays in the completion of the project and possible fraud (Bia, 2018; Chand, 2019b). At the end of May 2019, the Lagilagi Housing Project was taken over by the Fiji government. The PCN director as well as the members of the PCN Board face legal investigation (Chand 2019a; see also Walsh, 2019). Similar allegations exist for the Raiwai apartments of the PRB. In September 2019 the PRB announced that two thirds of the Raiwai apartment tenants (140 out of 210 ) had received eviction notices as their incomes are higher than allowed to be eligible to occupy a flat (Chand 2019c).

Apartments built for poorer sections of Suva's population are more and more often occupied by people who are financially better off. Those for whom the apartments were ostensibly built have to move further away, to the rim of the city, to areas others are not much interested in. Today, such places are difficult to find.

The dynamics that exist in the Lagilagi apartments and the PRB apartments in Raiwai might give an indication of what will happen to Muanivatu once water and insufficient sanitation no longer make this settlement a 'dangerous place'. Then poor and vulnerable settlers might have to leave.

A similar situation has been observed in the Namadai informal settlement in the high-value residential area of Namadi Heights in Tamavua, which was upgrad-

\footnotetext{
${ }^{1}$ Fiji had a military coup in December 2006 and elections were postponed until September 2014. In the 2014 election campaign and election manifestos of various parties the issues of informal settlements played an important role.
} 
ed in 1993 by the Methodist Church of Fiji though the government's Poverty Alleviation Fund. Land tenure is freehold. At that time, residents were allocated a block of land. In a recent estimation of home ownership in Namadai, around 30\% who live there now and own houses or land are not original residents. In the meantime, higher-income eamers and owners of real estate businesses have moved to the area, crowding out poorer residents. Most of the poorer families settle now squatting along a highway unable to improve their lives (Koto, 2008).

\section{Conclusion}

More research needs to be done to get better insights into the reasons why people moved for the first time to a particular place. The beginning of an informal settlement plays a central role in this question as later people move to places that have been established: it has then become a place that has demonstrated that it is 'safe' from eviction. Results of our initial research indicate that living in challenging environmental locations enhances people's security from being evicted.

Reflexivity appears to play an important role: people's moves to urban areas are usually not planned in every detail. They are often more trial-and-error approaches, with people learning from success and failure. Through such mechanisms, informal settlements in relatively safe locations emerge, while less safe locations are easily rejected or abandoned, often by force of the relevant authorities.

It has been established that there are different forms of security: in the cases observed in this study, 'security of a healthy environment' is traded in for 'security from eviction'. This mechanism is well understood by people who make these decisions. In their search for security, people are even willing to live in environments that are harmful to their health. Notions of forced migration do not really apply to such situations as a "forced migration concept" assumes that dangers that make people move exist in the places of origin. Climate change-related impacts are often constructed as such dangers from which people try to escape through their movements. What is happening in the cases of the informal settlements investigated in Suva turns the entire concept on its head: people leave their relatively safe homes in rural areas and move to environmentally dangerous places in urban areas. This is done to enhance overall security by diversifying sources of livelihood. In such strategies, the notion of translocality plays a crucial role: the diversification of livelihood sources only works when households split up and work in different locations and different modes of production, from subsistence/semi-subsistence production in the villages to (in some cases) international capitalist modes of production in urban centres.

Security - which people are looking for - has many risks and uncertainties, especially in dynamic economic environments such as the one of Suva. A couple of decades ago nobody showed much interest in the land the settlements have been built on. Today the area is prime real estate property. The fear is not unjustified 
that it won't take long before those who now live in informal settlements will find themselves further marginalised. It is not unrealistic to assume that, over the years, residents will be required to move out of the apartments built by the PRB and the PCN, apartments first built for those living in informal settlements. People who are financially better off will replace them. The same fate might also await those residents of informal settlements who participate in the RISE project: as soon as the environmental conditions in these settlements improve considerably, the locations will become vulnerable to the greed of people who are better off.

For climate change considerations, the first lesson to learn is to avoid the need for migration as much as possible by making the places where migrants come from, the rural areas, not only 'safe', but also places where people can achieve their material aspirations. If mobility is part of a strategy of livelihood diversification and risk minimisation, then people don't need to migrate if they can achieve this in the places they are living. Here some insights might be provided by Kadavu Island in the very south of Fiji. Because of the destruction of Tropical Cyclone Winston, prices for kava, the national drink of Fiji, increased by the factor of 4-5. Kava plants of farmers in Kadavu were not destroyed. Today, farmers on Kadavu benefit greatly from the huge price increase. There is much visible evidence that this gave a strong push to material development on Kadavu. There is even anecdotal evidence that people returned to the island to start businesses there.

In Suva's informal settlements it is urgent to upgrade housing structures. As mentioned earlier, material damages and death tolls will be huge if a high intensity tropical cyclone hits these settlements. At the same time, it is essential to mitigate environmental health challenges in these settlements and to include safeguards so that people are not crowded out by better-off sections of Suva's society, when these locations are upgraded and look neat and clean. The experience of the PCN's Lagilagi apartments shows that there are limitations to preventing this special form of gentrification from happening. It appears that safeguards that were installed did not work well.

\section{Bibliography}

Adger, W. N., \& Fortnam, M. (2018). Interactions of migration and population dynamics with ecosystem services. In K. Schreckenberg, G. Mace, \& M. Poudyal (Eds.), Ecosystem Services and Poverty Alleviation (pp. 103-119). London and New York: Routledge.

Ajak, B. J. (2018). Livelihood resilience and adaptation to climate variability in post-conflict South Sudan: A review. Agricultural Reviews, 39(3), 193-201.

Archer, M. S. (2007). Making our way through the world: Human reflexivity and social mobility. Cambridge: Cambridge University Press.

Archer, M. S. (2010). Conversations about reflexivity. Abingdon and New York: Routledge. 
Asian Coalition For Housing Rights in Suva, Fiji. (n.d.). The informal settlements of Fiji. Retrieved from http://informalism.blogspot.com/2010/04/asian-coaltionfor-housing-rights-in.html.

Asian Development Bank (ADB). (2012). Key Indicators for Asia and the Pacific 2012. Manila, Philippines. Retrieved from http://www.adb.org/statistics.

Augustijn-Beckers, E. W., Flacke, J., \& Retsios, B. (2011). Simulating informal settlement growth in Dar es Salaam, Tanzania: An agent-based housing model. Computers, Environment and Urban Systems, 35(2), 93-103.

Babere, N. J. (2015). Social production of space: "Lived space" of informal livelihood operators; the case of Dares Salaam City Tanzania. Current Urban Studies, 3(4), 286-299.

Bargatzky, T. (1980). Beachcombers and castaways as innovators. The Journal of Pacific History, 15(2), 93-102.

Barnett, J., \& Adger, W. N. (2003). Climate dangers and atoll countries. Climatic Change, 61(3), 321-337.

Begum, F. (2018, October 25). Residents of Nanuku and Veidogo settlements to be relocated in the next 9-12 months. FijiVillage. Retrieved from https:// fijivillage.com/news/Residents-of-Nanuku-and-Veidogo-settlementsto-be-relocated-in-the-next-9-12-months---AG-2kr95s.

Bertram, I. G., \& Watters, R. F. (1985). The MIRAB economy in South Pacific microstates. Pacific Viempoint, 26(3), 497-519.

Bertram, G., \& Watters, R. F. (1986). The MIRAB process: Earlier analyses in context. Pacific Viempoint, 27(1), 47-59.

Bia, A (2018, November 19). PCN needs \$1.2M to complete Lagilagi Housing Project. Fiji Broadcasting Corporation. Retrieved from https://www.fbcnews.com .fj/news/pcn-needs-1-2m-to-complete-lagilagi-housing-project/.

Biermann, F. (2001). Umweltflüchtlinge. Ursachen und Lösungsansätze. Aus Politik und Zeitgescbichte, B12, 24-29.

Bohle, H.-G., \& Fünfgeld, H. (2007). The political ecology of violence in Eastern Sri Lanka. Development and Change, 38(4), 665-687.

Bryant, J. (1992). Poverty in Fiji: Who are the urban poor? Singapore Journal of Tropical Geography, 13(2), 90-102.

Bryant, J. (1993). Urban poverty and the environment in the South Pacific. Armidale: Department of Geography and Planning, University of New England.

Bryant-Tokalau, J. (1995). The myth exploded: Urban poverty in the Pacific. Environment and Urbanization, 7(2), 109-130.

Bryant-Tokalau, J. (2010). The Fijian Qoliqoli and urban squatting in Fiji: Righting an historical wrong? Melbourne: Alfred Deakin Research Institute, Deakin University.

Bryant-Tokalau, J. (2012). Twenty years on: Poverty and hardships in urban Fiji. Bijdragen tot de Taal-Land-en Volkenkunde/Journal of the Humanities and Social Sciences of Southeast Asia and Oceania, 168(2), 195-218.

Bryant-Tokalau, J. (2014). Urban squatter and the poor in Fiji: Issues of land and investment in coastal areas. Asia Pacific Viewpoint, 55(1), 54-66. 
Bunker, S. G. (1984). Modes of extraction, unequal exchange, and the progressive underdevelopment of an extreme periphery: The Brazilian Amazon, 1600-1980. American Journal of Sociology, 89(5), 1017-1064.

Bunker, S. G. (1988). Underdeveloping the Amazon: Extraction, unequal exchange, and the failure of the modern state. Chicago: University of Chicago Press.

Butcher-Gollach, C. (2015). Planning, the urban poor and climate change in Small Island Developing States (SIDS): Unmitigated disaster or inclusive adaptation? International Development Planning Review, 37(2), 225-248.

Butcher-Gollach, C. (2018). Planning and urban informality—Addressing inclusiveness for climate resilience in the Pacific. In W. L. Filho (Ed.), Climate Change Impacts and Adaptation Strategies for Coastal Communities (pp. 43-68). Cham: Springer.

Campbell, I. C. (1998). "Gone native" in Polynesia: Captivity narratives and experiences from the South Pacific. Westport, CT: Greenwood Press.

Carling, J., \& Collins, F. (2018). Aspiration, desire and drivers of migration. Journal of Ethnic and Migration Studies, 44(6), 909-926.

Carmo, R. M., \& Hedberg, C. (2018). Translocal mobility systems: Social inequalities and flows in the wild berry industry. Geoforum, 99, 102-110.

Chand, S. (2019a, May 31). Government takes over Lagilagi project after alleged abuse of funds. Fiji Sun. Retrieved from https:// fijisun.com.fj/2019/05/31/.

Chand, S. (2019b, June 25). Father Barr Breaks Silence On Lagilagi Housing Project. Fiji Sun. Retrieved from https:// fijisun.com.fj/2019/06/25/.

Chand, S. (2019c, September 19). 140 tenants of Raiwai flats issued eviction notice, no longer eligible to occupy flats. Fiji Sun. Retrieved from https:// fijisun.com.fj/2019/09/19/.

Chandra, R. (1985). Industrialization in Fiji (Doctoral dissertation, University of British Columbia).

Cochrane, L., \& Cafer, A. (2018). Does diversification enhance community resilience? A critical perspective. Resilience, 6(2), 129-143.

Cocklin, C., \& Keen, M. (2000). Urbanization in the Pacific: Environmental change, vulnerability and human security. Environmental Conservation, 27(4), 392-403.

Davidson, D. J. (2012). Analysing responses to climate change through the lens of reflexivity. The British Journal of Sociology, 63(4), 616-40.

de Haan, A. (2000). Migrants, livelihoods, and rights: The relevance of migration in development policies. Social Development Working Paper No. 4. London: United Kingdom Department for International Development.

De Haan, L., \& Zoomers, A. (2005). Exploring the frontier of livelihoods research. Development and Change, 36(1), 27-47.

de Haas, H. (2006). Turning the tide? Why "development instead of migration" policies are bound to fail. Working Paper No. 2. Oxford: International Migration Institute-University of Oxford.

Dorigo, G., \& Tobler, W. (1983). Push-pull migration laws. Annals of the Association of American Geographers, 73(1), 1-17. 
Duda, I., Fasse, A., \& Grote, U. (2018). Drivers of rural-urban migration and impact on food security in rural Tanzania. Food Security, 10, 785-798.

Ebenezer, M., \& Abbyssinia, M. (2018). Livelihood diversification and its effect on household poverty in Eastern Cape Province, South Africa. The Journal of Developing Areas, 52(1), 235-249.

Etzold, B., \& Sakdapolrak, P. (2016). Socio-spatialities of vulnerability: Towards a polymorphic perspective in vulnerability research. Die Erde, 147(4), 234-251.

Fazey, I., Moug, P., Allen, S., Beckmann, K., Blackwood, D., Bonaventura, M., ... Harkness, R. (2018). Transformation in a changing climate: A research agenda. Climate and Development, 10(3), 197-217.

Fiji Bureau of Statistics. (2018). Key Statistics. Retrieved from https://www.statsfiji.gov.fj/index.php/latest-releases/key-stats.

Fleischer, F. (2007). "To choose a house means to choose a lifestyle." The consumption of housing and class structuration in urban China. City \& Society, 19(2), 287-311.

Foukona, J. (2015). Urban land in Honiara: Strategies and rights to the city. The Journal of Pacific History, 50(4), 504-518.

Friedman, R., Hirons, M. A., \& Boyd, E. (2018). Vulnerability of Ghanaian women cocoa farmers to climate change: A typology. Climate and Development, 11(5), 446-458.

Friend, R. M., Thinphanga, P., MacClune, K., Henceroth, J., Tran, P. V. G., \& Nghiem, T. P. (2015). Urban transformations and changing patterns of local risk: Lessons from the Mekong Region. International Journal of Disaster Resilience in the Built Environment, 6(1), 30-43.

Galtung, J. (1975). Strukturelle Gewalt. Beiträge zur Friedens-und Konfliktforschung. Reinbek bei Hamburg: Rowohlt.

Government of Fiji. (2006). Urban Growth Management Plan (UGMAP) for the Greater Suva Region. Suva: Ministry of Local Government \& Urban Development.

Hill, A., \& Lindner, C. (2010). Modelling informal urban growth under rapid urbanisation: A CA-based land-use simulation model for the city of Dar es Salaam, Tanzania. Dortmund, Germany: Technische Universität Dortmund.

Huang, Q., Parker, D. C., Filatova, T., \& Sun, S. (2014). A review of urban residential choice models using agent-based modeling. Environment and Planning B: Planning and Design, 41(4), 661-689.

Islam, M. M., \& Herbeck, J. (2013). Migration and translocal livelihoods of coastal small-scale fishers in Bangladesh. The Journal of Development Studies, 49(6), 832-845.

Jones, P. (2012a). Pacific urbanisation and the rise of informal settlements: Trends and implications from Port Moresby. Urban Policy and Research, 30(2), 145-160.

Jones, P. (2012b). Searching for a little bit of utopia - Understanding the growth of squatter and informal settlements in Pacific towns and cities. Australian Planner, 49(4), 327-338.

Jones, P. (2016a). Informal urbanism as a product of socio-cultural expression: Insights from the Island Pacific. In S. Attia, S. Shabka, Z. Shafik, \& A. Ibrahim (Eds.), Dynamics and Resilience of Informal Areas (pp. 165-181). Cham: Springer. 
Jones, P. (2016b). The emergence of Pacific urban villages: Urbanization trends in the Pacific Islands. Manila: Asian Development Bank.

Jurjonas, M., \& Seekamp, E. (2018). Rural coastal community resilience: Assessing a framework in eastern North Carolina. Ocean \& Coastal Management, 162, 137-150.

Keck, M., \& Sakdapolrak, P. (2013). What is social resilience? Lessons learned and ways forward. Erdkunde, 67(1), 5-19.

Keen, M., Barbara, J., Carpenter, J., Evans, D., \& Foukona, J. (2017). Urban development in Honiara. Harnessing opportunities, enbracing change. Canberra: State, Society and Governance in Melanesia Program, Australian National University.

Kiddle, G. (2010a). Contemporary urban squatting in Fiji: Recent trends, intervention and a potential policy framework. Fijian Studies, 8(1), 83-97.

Kiddle, G. (2010b). Perceived security of tenure and housing consolation in informal settlements: Case studies from urban Fiji. Pacific Economic Bulletin, 25(3), 203-205.

Kiddle, G. L. (2011). Informal settlers, perceived security of tenure and housing consolidation: Case studies for urban Fiji (Doctoral dissertation, Victoria University of Wellington).

Kiddle, L., \& Hay, I. (2017). Informal settlement upgrading: Lessons from Suva and Honiara. The Development Bulletin, 78.

Kiddle, G., McEvoy, D., Mitchell, D., Jones, P., \& Mecartney, S. (2017). Unpacking the Pacific urban agenda: Resilience challenges and opportunities. Sustainability, 9(10), 1878.

Koto, C. W. (2008). Coping strategies of Fïi's urban poor: A case study of Namadai settlement, Swva, Fiji Islands (Master's thesis, The University of the South Pacific, Suva).

Lee, E. (1966). A theory of migration. Demography, 3(1), 47-57.

Lohnert, B., \& Steinbrink, M. (2005). Rural and urban livelihoods: A translocal perspective in a South African context. South African Geographical Journal, 87(2), 95-103.

Loibl, W., \& Tötzer, T. (2003). Modeling growth and densification processes in suburban regions-Simulation of landscape transition with spatial agents. Environmental Modelling \& Software, 18(6), 553-563.

Lonergan, S. (1998). The role of environmental degradation in population displacement. Environmental Change and Security Project Report, 4(Spring), 5-15.

Long, N. (2001). Development sociology: Actor perspectives. London: Routledge.

Marino E. (2018). Sea level rise and social justice: The social construction of climate change driven migrations. In C. Murphy, P. Gardoni, \& R. McKim (Eds.), Climate change and its impacts. Climate change management (pp. 181-193). Cham: Springer.

McAdam, J. (2015). Relocation and resettlement from colonisation to climate change: The perennial solution to 'danger zones'. London Review of International Law, 3(1), 93--130.

McDowell, C., \& de Haan, A. (1997). Migration and sustainable livelihoods: A critical review of the literature. IDS Working Papers 67. Sussex: Institute of Development Studies. 
McDowell, G., Ford, J., \& and Jones, J. (2016). Community-level climate change vulnerability research: Trends, progress, and future directions. Environmental Research Letters 11(3), 033001.

Mecartney, S., \& Connell, J. (2017). Urban Melanesia: The challenges of managing land, modernity and tradition. In S. McDonnell, M. Allen, \& C. Filer (Eds.), Kastom, Property and Ideology: Land Transformations in Melanesia (pp. 57-84). Canberra: Australian National University Press.

Milcaims, S. W. (2006). Native strangers: Beachcombers, renegades and castaways in the South Seas. Auckland: Penguin.

Mohanty, M. (2006a). Urban squatters, the informal sector and livelihood strategies of the poor in Fiji Islands. Development Bulletin 70, 65-68.

Mohanty, M. (2006b). Poverty, environmental hazards and vulnerability of urban poor in small island states: A case of squatter communities in Suva city, Fiji Islands. In F. H. Feng, L. Yu, \& W. Solecki (Eds.), Urban dimensions of environmental Change: Science, exposures, policies and technologies (pp. 231-236). New Jersey: Science Press.

Moore, C. (2015). Honiara: Arrival city and Pacific hybrid living space. The Journal of Pacific History, 50(4), 419-436.

Mukhtar, U., Zhong, Z., Tian, B., Razzaq, A., Naseer, M., \& Hina, T. (2018). Does rural-urban migration improve employment quality and household welfare? Evidence from Pakistan. Sustainability, 10(11), 4281.

Mycoo, M., \& Donovan, M. G. (2017). A blue urban agenda: Adapting to climate change in the coastal cities of Caribbean and Pacific Small Island Developing States. Bogota, Columbia: Inter-American Development Bank.

Naidu, V., \& Reddy, M. (2002). ALTA and expiring land leases: Fijian farmers' perceptions of their future. Suva: Centre for Development Studies, USP and Pacific Migration Research Network (PacMRN).

Nanuku, Veidogo squatters look forward to relocation. Fiji Sun (2018, October 27). Retrieved from https:// fijisun.com.fj/2018/10/.../nanuku-veidogosquatters-look-forward-to-relocation.

Otsuki, K., Jasaw, G., \& Lolig, V. (2018). Linking individual and collective agency for enhancing community resilience in Northern Ghana. Society \& Natural Resources, 31(2), 151-165.

Pratibha, J. (2016, July 15). Goodwill To Squatters Chance Of A Lifetime. Fiji Sun. Retrieved from https://fijisun.com.fj/2016/07/15/goodwill-to-squatterschance-of-a-lifetime/.

Prowse, M. (2010). Integrating reflexivity into livelihoods research. Progress in Development Studies, 10(3), 211-231.

Rainima, T. (2016, Junly 24). Vatuwaqa squatters accept relocation to Makoi. Fiji Broadcasting Corporation. Retrieved from https://www.fbcnews.com.fj/news /vatuwaqa-squatters-accept-relocation-to-makoi/.

Ralston, C. (1977). Grass buts and warehouses: Pacific beach communities of the nineteenth century. Canberra: Australian National University Press. 
Ravenstein, E. G. (1885). The laws of migration. Journal of the Statistical Society, 48(2), $167-235$.

Ravenstein, E. G. (1889). The laws of migration: Second paper. Journal of the Royal Statistical Society, 52(2), 241-305.

Reza, M. (2017). Slum upgrading: Is realistic option for improving living condition amongst slum dwellers in Kloofkamp Jayapura. International Journal of Technology and Sciences, 1(1), 11-19.

Rockenbauch, T., \& Sakdapolrak, P. (2017). Social networks and the resilience of rural communities in the Global South: A critical review and conceptual reflections. Ecology and Society, 22(1), 10.

Sakdapolrak, P., Naruchaikusol, S., Ober, K., Peth, S., Porst, L., Rockenbauch, T., \& Tolo, V. (2016). Migration in a changing climate. Towards a translocal social resilience approach. Die Erde, 147(2), 81-94.

Schiller, N. G., Basch, L., \& Szanton Blanc, V. (1995). From immigrant to transmigrant: Theorizing transnational migration. Anthropological Quarterly, 68(1), 48-63.

Schilling, C. (2012). The body and social theory. London: Sage.

Shanal, S. (2016, July 15). Vatuwaqa squatters to be relocated soon. Fiji Broadcasting Corporation. Retrieved from https://www.fbcnews.com.fj/news/vatuwaqasquatters-to-be-relocated-soon/.

Singh, A. K., Singh, S. P., \& Singh, H. P. (2015). Measurement of employment, unemployment and underemployment of agricultural labour in tarai regions of Uttaranchal State and Uttar Pradesh. International Journal of Agriculture, Environment and Biotechnology, 8(1), 219-225.

Smith, C. A. (1984). Forms of production in practice: Fresh approaches to simple commodity production. The Journal of Peasant Studies, 11(4), 201-221.

Steinbrink, M. (2009). Urbanisation, poverty and translocality: Insights from South Africa. African Population Studies, 23(Suppl), 220-252.

Stephan-Emmrich, M., \& Schröder, P. (Eds.). (2018). Mobilities, boundaries, and travelling ideas: Rethinking translocality beyond Central Asia and the Caucasus. Cambridge, U.K: Open Book Publishers.

Tian, Q., \& Lemos, M. C. (2018). Household livelihood differentiation and vulnerability to climate hazards in rural China. World Development, 108, 321-331.

Trundle, A. (2017). Governance and agency beyond boundaries: Climate resilience in Port Vila's peri-urban settlements. In S. Moloney, H. Fünfgeld, \& M. Granberg (Eds.), Local Action on Climate Change: Opportunities and Constraints (pp. 47-64). London and New York: Routledge.

United Kingdom, The Government Office for Science. (2011). Foresight: Migration and global environmental change: Final project report. London: The Government Office for Science.

Vakasukawaqa, A. (2016, July 13). You're Not Forgotten: A-G Assures Squatters. Fiji Sun. Retrieved from https://fijisun.com.fj/2016/07/13/youre-notforgotten-a-g-assures-squatters/. 
Van Hear, N., Bakewell, O., \& Long, K. (2018). Push-pull plus: Reconsidering the drivers of migration. Journal of Ethnic and Migration Studies, 44(6), 927-944.

Vernez, G. (1974). Residential movements of low-income families: The case of Bogotá, Colombia. Land Economics, 50(4), 421-428.

Walsh, C. (2019). The Lagilagi controversy. Government and the People's Community Network, Part I, II and other information. Coz Walsh's blog. Retrieved from https://crosbiew.blogspot.com/search?q=lagilagi.

Weber, E. (2005). Sugar in Fiji - A dying sector? The Indian Geographical Journal, 80(2), 71-78.

Weber, E. (2007a). Gewalt und Staatsversagen in Fidschi. Journal für Wirtschaftsgeographie, 51(3-4), 206-220.

Weber, E. (2007b). Zucker auf Fidschi und die EU Agrarreform. Neuendettelsau: PazifikInformationsstelle.

Weber, E. (2012). Gandhi, Galtung und Globalisierung. Ländliche Entwicklung in Indien 19472011. Göttingen: Cuvillier Verlag.

Weber, E. (2014). Environmental change and (im)mobility in the South. In R. Anich, J. Crush, S. Melde, \& J. O. Oucho (Eds.), A newperspective on human mobility in the South (pp. 119-148). Global Migration Issues 3. Dordrecht: Springer.

Weber, E. (2015). Envisioning South-South relations in the fields of environmental change and migration in the Pacific Islands-past, present and futures. Bandung: Journal of the Global South, 2(1), 1-21.

Weber, E. (2016). Only a pawn in their games? Environmental (?) migration in Kiribati-past, present and future. Die Erde-Journal of the Geographical Society of Berlin, 147(2), 153-164.

Weber, E. (2017). Trade agreements, labour mobility and climate change in the Pacific Islands. Regional Environmental Change, 17(4), 1089-1101.

Woodhouse, E., \& McCabe, J. T. (2018). Well-being and conservation: Diversity and change in visions of a good life among the Maasai of northern Tanzania. Ecology and Society, 23(1), 43.

Yalew, A., Hirte, G., Lotze-Campen, H., \& Tscharaktschiew, S. (2018). Climate change, agriculture, and economic development in Ethiopia. Sustainability, 10(10), 3464.

Yeboah, F. K., \& Jayne, T. S. (2018). Africa's evolving employment trends. The Journal of Development Studies, 54(5), 803-832. 